\title{
Innovating with Pedagogy-Space-Technology (PST) Framework: The Online Moot Court
}

\author{
Jenny $\mathrm{Ng}$ \\ School of Law, Charles Darwin University, Australia \\ jenny.ng@cdu.edu.au
}

Keywords: Pedagogy-Space-Technology, PST, online moot court, teaching space, innovation

\begin{abstract}
The Pedagogy-Space-Technology (PST) Framework (Radcliffe, 2009) is a framework that has been used to guide the creation of new and modern teaching spaces. This paper highlights the journey of an Innovation@CDU Grant Project which uses the PST Framework to build an online moot court which is able to ensure that both internal students on campus and external students online are able to moot effectively. The project uses Blackboard Collaborate ${ }^{\mathrm{TM}}$ and the PST Framework. The technology has been implemented in Charles Darwin University (CDU) to create the new teaching spaces in CDU. The same technology in the new teaching spaces is then used to build an online moot court. The paper explains the PST Framework and discusses how the framework has been used and applied to further innovations such as an online moot court. It also explains the project's journey and the challenges and successes of the project. The research also includes the experiences and observations of the author who is the Project Leader of the Innovation@CDU Grant Project.
\end{abstract}

\section{Introduction}

I was introduced to the new teaching spaces in Charles Darwin University (CDU) that uses the Pedagogy-Space-Technology (PST) Framework (Radcliffe, 2009) and Blackboard Collaborate ${ }^{\mathrm{TM}}$ back in 2013. I had found using these new teaching spaces to be an enjoyable experience, and so I started to innovate by using the PST Framework to build an online moot court. A moot court simulates a hearing that is conducted in a real court room. The online moot court enables both internal students (on campus students) and external students (online students) to role-play as lawyers, which is a learning tool for law students known as 'mooting'. This project was part of the Innovation@CDU Grant Project, where I was the Project Leader. In this project, I intended to bring the virtual and physical worlds together so that both my internal and external students can moot effectively between themselves.

\section{The PST Framework}

Higher education institutions have an interest in creating new types of teaching spaces which support learner-centred or constructivist pedagogy. The best learning outcomes are generated through a constructivist pedagogical approach (Brown, 2005; Ehrmann, 1995; Valiant, 1996).

PST is the product of a Carrick Institute-funded Next Generation Learning Spaces (NGLS) project, which was conducted in University of Queensland by Professor Radcliffe. It guides the 
design and operation of new learning spaces (Radcliffe, 2009). It was developed collaboratively and based on existing key research in this area of teaching and learning (e.g., Oblinger, 2005). The NGLS project develops the PST framework by examining the relationship between pedagogy, space and technology. It aims to enable institutions to create new teaching and learning spaces with the objectives of promoting student engagement and learning outcomes. It is an inquiry driven process that is based on Pedagogy, Space and Technology (see Table 1) and thus, can be suited to the specific needs of the institution.

The life cycle, the design stage and the evaluation stage

The PST framework provides for a more systemic manner in achieving the right balance between pedagogy, space and technology in designing and evaluating new learning spaces. This is a more balanced approach as many new facilities have begun its implementation with pedagogical intent, but the end product of the actual spaces often reflects technological, architectural, or operational considerations (Radcliffe, 2009).

The PST framework is a question-driven inquiry process. The framework was a result of synthesizing the relevant published literature and knowledge of innovative teaching and learning spaces, as well as being informed by The University of Queensland's (UQ) experiences in developing new learning facilities.

Table 1: Life Cycle

\begin{tabular}{|c|c|c|}
\hline Focus & Conception and Design & Implementation and Operation \\
\hline \multirow[t]{2}{*}{ Overall } & $\begin{array}{l}\text { What is the motivation for the } \\
\text { initiative? }\end{array}$ & What does success look like? \\
\hline & $\begin{array}{l}\text { What is intended? What } \\
\text { initiated the project? Who } \\
\text { are the proponents and } \\
\text { opponents? Who has to be } \\
\text { persuaded about the idea? } \\
\text { Why? What lessons were } \\
\text { learned for the future? }\end{array}$ & $\begin{array}{l}\text { Is the facility considered to } \\
\text { be a success? By whom? } \\
\text { Why? What is the evidence? } \\
\text { Does this relate to the original } \\
\text { motivation or intent? } \\
\text { - What lessons were learned for } \\
\text { the future? }\end{array}$ \\
\hline \multirow[t]{2}{*}{ Pedagogy } & $\begin{array}{l}\text { What type(s) of learning and } \\
\text { teaching are we trying to foster? } \\
\text { Why? }\end{array}$ & $\begin{array}{l}\text { What type(s) of learning and } \\
\text { teaching are observed to take } \\
\text { place? }\end{array}$ \\
\hline & $\begin{array}{l}\text { Why is this likely to make a } \\
\text { difference to learning? } \\
\text { - What is the theory \& evidence? } \\
\text { - What plans will be made to } \\
\text { modify programs or courses } \\
\text { to take advantage of the new } \\
\text { facilities? } \\
\text { - What education or training for } \\
\text { academics and other staff is } \\
\text { built into the plan? }\end{array}$ & $\begin{array}{l}\text { What evaluation methodology } \\
\text { or approach was used and } \\
\text { what methods were used to } \\
\text { gather and analyse data? } \\
\text { - Who was included in the } \\
\text { data gathering and analysis? } \\
\text { Students? Faculty? Staff? } \\
\text { Administrator? Senior } \\
\text { Leadership? Facilities } \\
\text { managers and technology } \\
\text { staff? }\end{array}$ \\
\hline
\end{tabular}




\begin{tabular}{|c|c|c|}
\hline Focus & Conception and Design & Implementation and Operation \\
\hline \multirow[t]{2}{*}{ Space } & $\begin{array}{l}\text { What aspects of the design of } \\
\text { the space and provisioning of } \\
\text { furniture and fittings will foster } \\
\text { these modes of learning (and } \\
\text { teaching)? How? }\end{array}$ & $\begin{array}{l}\text { Which aspects of the space } \\
\text { design and equipment worked } \\
\text { and which did not? Why? }\end{array}$ \\
\hline & $\begin{array}{l}\text { Who is involved in developing } \\
\text { the design brief? Why? } \\
\text { Which existing facilities will } \\
\text { be considered in developing } \\
\text { concepts? Can we prototype } \\
\text { ideas? } \\
\text { - Who is involved in the } \\
\text { assessment of concepts and } \\
\text { detailed design? Why? What } \\
\text { are their primary issues and } \\
\text { concerns? }\end{array}$ & $\begin{array}{l}\text { What were the unexpected } \\
\text { (unintended) uses of the } \\
\text { space and facilities that } \\
\text { aided learning or facilitated } \\
\text { teaching? Do these present } \\
\text { ideas for future projects? } \\
\text { - How was the effectiveness } \\
\text { of the use of space to } \\
\text { aid learning and teaching } \\
\text { measured? What were the } \\
\text { different metrics used? } \\
\text { Were there synergies between } \\
\text { this and other spaces that } \\
\text { enhanced learning? }\end{array}$ \\
\hline \multirow[t]{2}{*}{ Technology } & $\begin{array}{l}\text { What technology will be } \\
\text { deployed to complement the } \\
\text { space design in fostering the } \\
\text { desired learning and teaching } \\
\text { patterns? }\end{array}$ & $\begin{array}{l}\text { What technologies were most } \\
\text { effective in enhancing learning } \\
\text { and teaching? Why? }\end{array}$ \\
\hline & $\begin{array}{l}\text { In establishing the brief and } \\
\text { developing concepts and } \\
\text { detailed designs, what is } \\
\text { the relationship between the } \\
\text { design of the space and the } \\
\text { selection and integration of } \\
\text { technology? } \\
\text { What pedagogical } \\
\text { improvements are suggested } \\
\text { by the technology? }\end{array}$ & $\begin{array}{l}\text { What were the unexpected } \\
\text { (unintended) impacts } \\
\text { (positive and negative) of the } \\
\text { technology on learning and } \\
\text { teaching? } \\
\text { - How did technology enhance } \\
\text { the continuum of learning and } \\
\text { teaching across the campus } \\
\text { and beyond? }\end{array}$ \\
\hline
\end{tabular}

Source: Radcliffe, Wilson, Powell, Tibbetts, (2009) Learning Spaces in Higher Education

Table 1 illustrates the basic questions in the life cycle of the implementation of new facility in the PST Framework. It can be used for any type of learning spaces. It can be applied to projects of all sizes.

The three items in the framework - pedagogy-space-technology - are intentionally arranged as such, and this sequence is important in the framework. Pedagogy, space and technology, have an inter-relationship and influence each other. The learning space's shape and arrangement 
will influence the pedagogical attributes, although it does not mean that the framework values pedagogy over space or technology. This pedagogy-space-technology loop will go through an iterative process in the implementation stages and the iteration would occur several times at each stage of the life-cycle of a learning space. While Table 1 shows only two life cycle stages, the table could be adapted into more complex structures which have more than two columns.

The PST framework expresses clearly that the evaluation in ascertaining the degree to which the original goals were met are focused on the defined pedagogic goals. Whilst the PST framework does not deny that the goal of improving learning outcomes is important, it does not evaluate it directly. The goals of the space are defined in terms of fostering particular modes or patterns of teaching and learning. The primary evaluation is to ascertain whether such patterns of teaching and learning are observed and which aspects of the space and technology are able to encourage and improve these types of teaching and learning activities. The PST Framework consists of the design and evaluation stages.

\section{Developing the PST Framework (the design stage)}

The constructivist learning theory is based on the learning that students achieve by understanding the subject matter through their activities. Traditional learning spaces usually do not provide for such opportunities that will enable constructivist learning to occur. There is no single approach for the creation of teaching spaces that enables constructivist learning to occur. The Designing Spaces for Effective Learning Report (JISC, 2006) argues that "a learning space should be able to motivate learners and promote learning as an activity, support collaborative as well as formal practice, provide a personalised and inclusive environment, and be flexible in the face of changing needs". Oblinger (2005) takes a more student centric approach to the design of these learning spaces. Jamieson et al. (2000) adopts multi-disciplinary approaches which includes "augmenting rather than replacing in toto existing design principles"). Denison University's (Ohio) Learning Spaces Project aims to "enhance the utility, appearance and comfort of all campus spaces related to learning. Learning spaces must support many styles of learning, be versatile, comfortable and attractive, rich with information and reliable technology, maintained and accessible" (Siddall, 2006).

Johnson and Lomas (2005) create "an iterative dialogue among the design team and other stakeholders in the design process". The process includes concepts in teaching and learning principles such as Chickering and Gamson's 'Seven Principles' (1987) or the NRC report on 'How People Learn' (Bransford et al., 2000).

Long and Ehrmann (2005) suggests the following ideas for future classrooms:

- $\quad$ Learning by doing matters;

- Context matters;

- Interaction matters; and

- $\quad$ Location of learning matters.

They list the factors that re important for building the 'classroom of the future' as:

- Designed for people, not for ephemeral technologies;

- $\quad$ Optimised for certain learning activities, not just stuffed with technology;

- Enabling technologies brought into the space, rather than built into the space;

- Allowing invisible technology and flexible use;

- Emphasising soft spaces; 
- Useful across the 24 hour day; and

- Zoned for sound and activity.

At this stage, the PST Framework will be incorporated into the planning and design of the teaching space and the four questions in the Life Cycle (Table 1) should be addressed accordingly. The four questions are:

1. What is the motivation for the initiative?

2. What type(s) of learning and teaching are we trying to foster? Why?

3. What aspects of the design of the space and provisioning of furniture and fittings will foster these modes of learning (and teaching)? How?

4. What technology will be deployed to complement the space design in fostering the desired learning and teaching patterns?

\section{Implementation and Operation (the evaluation stage)}

There are many ways that the evaluation of the new teaching spaces could be conducted. The more popular methods are such as head counts and multiple choice user satisfaction questions. Anecdotal evidence can also be used. However, research projects or design studies which inform ongoing development usually provide more detailed research. Thus, empirical measures and questioning with focus groups are used in such projects.

While learning outcomes are important, the PST Framework does not evaluate it directly. This is because learning outcomes depend on other variables beyond the space. The aims and objectives of the space are in fostering specific modes or patterns of teaching and learning. The primary evaluation is to ascertain whether or not such patterns in teaching and learning are achieved and which aspects of the space and technology are able to promote these teaching and learning activities. The questions to be address at this stage are:

- What does success look like?

- What type(s) of learning and teaching are observed to take place?

- Which aspects of the space design and equipment worked and which did not? Why?

- What technologies were most effective in enhancing learning and teaching? Why?

\section{Using the PST Framework: PST @ CDU and the online moot court}

CDU's new teaching spaces are in the form of classrooms and lecture halls which were built by using the PST Framework. I was able to teach both internal and external students simultaneously in these new teaching spaces. The main emphasis of the new teaching spaces was on collaborative teaching as the student demographics at CDU consists of $80 \%$ external students and $20 \%$ internal students. Thus, the collaborative teaching spaces, which was one of the new types of teaching spaces in Radcliffe's PST Framework was adopted in CDU.

The collaborative teaching spaces were designed to foster collaborative approaches to teaching and learning where both internal and external students can study together. This is by enabling the internal students and the lecturer in the physical learning spaces to communicate with the external students via videoconferencing or similar technologies. In this sense, it brings the physical and virtual worlds together.

The new teaching spaces in CDU consists of technology-enhanced classroom with collaborate tools. They are equipped with LCD Monitors, Glass writing walls, Cameras, Speakers and 
Collaborate cameras, Control Pads, Neck and handheld microphones, Wireless Keyboards, Interactive Pens and Document Cameras. The Collaborate Teaching Spaces blend Blackboard's Collaborate ${ }^{\mathrm{TM}}$ technology within the classrooms, reduce transactional distance, and provide the internal students with the opportunity to use devices for collaboration because of connectivity (wireless and ports).

\section{The Online Moot Project - The Innovation@CDU Grant Project}

Like most law schools, CDU has a moot court in the law school where students can practice their mooting skills. Mooting is a common law school teaching activity, whereby students argue hypothetical cases before moot court judges. It is an excellent learning tool, which enhances research, analytical, writing and advocacy skills. Mooting allows the students to develop a deeper and more thorough understanding of substantive legal principles, to argue a legal case by role playing as lawyers and to work collaboratively with team mates. However, the problem is that $80 \%$ of CDU's law students are external students. Thus, it would not be possible for them to use the moot court unless we are able to bring the moot court to them.

Thus, I thought of having an online moot court so that the external students can use the moot court over the Internet. This would enable the internal and external students to moot with each other, or amongst themselves. The idea of using the PST framework to build an online moot court came when I was observing the ability of CDU's new teaching spaces to bring the physical and virtual worlds together via Blackboard Collaborate ${ }^{\mathrm{TM}}$, as well as the inquiry driven process within the PST Framework. I thought it would be a good idea to replicate certain parts of the technology in the new teaching spaces in CDU into the moot court, as well as to adapt the new teaching spaces so that they can be turned into online moot courts. This makes it possible for students to moot in both the moot court and the new teaching spaces.

Within the grant project, I was able to ascertain the effectiveness of the online moot court and provide insights into what needs to be done to create an effective online mooting program, including in relation to technology. As part of the project, mooting was incorporated as part of the optional assessment in a second semester unit which I taught. My students were given a hypothetical problem and allocated roles as counsel for the plaintiff or counsel for the defendant, and prepared both written and oral submission for their arguments. The moot sessions (for external students) were held at the new teaching spaces as well as the moot court (once the new technologies that has been implemented in the new teaching spaces has been replicated in the moot court). It aims to replicate the modern online courts in Australia today. It also brings the physical and virtual space together so that external students and internal students are able to moot together, or amongst themselves.

\section{The PST Framework and the online moot court: The framework and design stage}

\section{What is the motivation for the initiative?}

The CDU Law School was considering integrating mooting into the curriculum. However, $80 \%$ of law students study online and there is a question of whether mooting can be effectively adapted to the online environment. Thus, I came about with the idea of having an online moot court that uses the PST Framework so that the external students can use the moot court over the Internet, and to ensure that the new teaching spaces are able to be adapted for such purposes. 
What type(s) of learning and teaching are we trying to foster? Why?

Mooting is known as a useful teaching tool for law students. According to Pope and Hill, mooting 'makes you think like a lawyer, improves your public speaking skills, is the best way to learn the law, gives you confidence, will help you find a job and is fun' (Pope and Hill, 2007). Mooting also involves acquiring cognitive skills (Thomas \& Cradduck, 2013). It is also a tool for deep doctrinal learning (Gerber \& Castan, 2013). Snape and Watt (Snape \& Watt, 2010) state that mooting helps inculcate a few skills such as:

1. the ability to explain complex legal material in a simple and clear manner;

2. dealing with interruptions and challenges;

3. teamwork;

4. the ability to 'disguise' the most detailed examination of the most technical of material in the most persuasive way;

5. skills of research and presentation which are 'absolutely interdependent'; and,

6. communication skills (Lynch, 1999).

According to Lebovits, Gewuerz and Hunker (2013):

Moot court enhances the three most important skills that law schools offer their students: starting an argument with a conclusion, differentiating fact from opinion, and organizing a legal argument by issue rather than by a chronological narrative of the facts.

Gygar and Cassimatis (1997) state:

it appears from the university experience that many disadvantaged students who were initially withdrawn and reticent about expressing their views in class situations gain enormously in confidence as a result of moots where they are able to demonstrate they can hold their own in any company.

Whilst most academics support the activity of mooting, it is also noted that Kozinski (1997) argues that mooting is not helpful in developing the right skills because moots are won by advocacy skills rather than the merits of the case. However, this has been counter-argued by Hernandez (1998) who replied to Kozinski's criticisms by stating that mooting develops writing and advocacy skills, character building and resume building. The benefits of mooting are also observed by Gaubatz (1981) who states:

too often overlooked is the academic benefit to be derived from a good moot court experience. the sort of analysis and synthesis implicit in arguing any appeal is the meat of legal education in the normal classroom. in the latter ... the pressure to 'move on' can even limit the benefit to the recite. But in the moot court the student has several weeks to dig into an analytic problem.

Courts around the world are now using technology to increase the efficiency and quality of the litigation process. Some universities, such as the University of Melbourne, have specifically focused on ensuring that students learn how to use the new technology as part of the court process and are trained in modern court room processes. ${ }^{1}$ Online mooting can help students

1. http://www.law.unimelb.edu.au/melbourne-law-school/experience/facilities-and-technology/moot-court 
acquire technology skills (Yule, McNamara \& Thomas, 2012). Thus, CDU Law School is interested in having a mooting programme that allows both external and internal students to moot online.

Furthermore, it has been stated that law schools should incorporate the use of technologies because modern lawyers need to have technological communication skills (Koo, 2009). Koo (2009) states that '[l]aw schools should leverage technology more effectively to accomplish the goal of skills transmission', and that they should '[u]tilize technology to create more effective simulations'. According to Clark (Macrae, 2001):

Legal educators must be prepared and able to educate tomorrow's lawyers who will work in law offices, which will operate in a dramatically different environment than that which exists in the majority of today's organisations.

Richards (2003) notes that law students who are not familiar with the Internet would be disadvantaged when they become lawyers, especially when they have to work within the context of court room technologies. Furthermore, the moot court would assist the externals students greatly as the look and feel of the moot court would enable them to learn to read nonverbal cues, such as facial expressions and body language, of the judge or the lawyers when speaking in court which are important in an adversarial environment.

It is also useful for students to learn to moot online as the courts have already begun using virtual courtrooms. In Australia, the Federal Court of Australia, has begun using virtual courtrooms, eFiling and eCase administration processes. De Wilde argued (2006) that litigation processes in Australia is 'transformed by the increasing use of courtroom technology'. According to Lord Woolf (1999), 'sensible investment in appropriate technology is fundamental to the future of our civil justice system'. The first 'electronic trial' heard in Queensland is Covecorp Constructions Pty Ltd v Indigo Projects Pty Ltd ${ }^{2}$ (Jackson, 2008). The development was consistent with the reforms suggested by Lord Woolf, as enunciated by Einstein $\mathrm{J}$ in Idoport Pty Ltd $v$ National Australia Bank Limited ('Idoport'). ${ }^{3}$

Covecorp Constructions Pty Ltd v Indigo Projects Pty Ltd² (Jackson, 2008). The development was consistent with the reforms suggested by Lord Woolf, as enunciated by Einstein $\mathrm{J}$ in Idoport Pty Ltd v National Australia Bank Limited ('Idoport'). ${ }^{3}$

In United States, for example, the College of William \& Mary and the National Centre for State Courts (NCSC) have experimented with the use of advanced technology and the Centre for Legal and Court Technology is the hub of the Courtroom 21 Project. ${ }^{4}$ Courtroom 21 is a model courtroom of the $21^{\text {st }}$ century. It is the most technologically advanced courtroom in the United States. Court 21 demonstrates how technology can enrich the legal process by assisting judges, counsel, jurors, court reporters and other court staff. Courtroom 21 uses only commercially available, and reasonably priced technology.

The first case, which admitted virtual reality evidence in the online context in Courtroom 21, is Stephenson v Honda Motors Ltd of America. ${ }^{5}$ Interestingly, Courtroom 21 was referred to by the University of Melbourne when creating their online moot court. ${ }^{6}$ 
What aspects of the design of the space and provisioning of furniture and fittings will foster these modes of learning (and teaching)? How?

I have developed the design of the online moot court after having several discussions with the Manager of the Higher Education and Training Development Department in CDU, who assisted in the Innovation@CDU Grant Project. The online moot court will continue to use the existing new teaching spaces, which use theater and semi-theater layouts, as well as the moot court at the law school. Some of the new teaching spaces in CDU are generally equipped with additional chairs and tables which make it easy to move around and convert the classroom into a make-shift moot court. The moot court in CDU Law School has a dual purpose - it has been used as a teaching space as well as a moot court.

What technology will be deployed to complement the space design in fostering the desired learning and teaching patterns?

The collaborative teaching spaces were designed to foster collaborative approaches to teaching and learning where both internal and external students can study together. This is by enabling the internal students and the lecturer in the physical learning spaces to communicate with the external students via videoconferencing or similar technologies, such as Blackboard Collaborate $^{\mathrm{TM}}$. In this sense, it brings the physical and virtual worlds together. The microphones installed at CDU are those from Rutledge Engineering, which provided for many different options. Both omni-directional microphones and uni-directional microphones have been used. An omni-directional microphone is able to capture about 6 people sitting around the microphone who are talking, whilst a uni-directional microphone is only able to capture the voice of the person talking in front of the microphone. The Faculty Online Resources Developer assisted with installing the new microphones at the moot court.

\section{Implementation and Operation of the Online Moot Project (the evaluation stage)}

\section{What does success look like?}

Success is generally in the form of both the pedagogical and technological aspects of the online mooting system working to the satisfaction of the students. I had measured the effectiveness of the online moot court based on some findings which were anecdotal evidence, student interviews, as well as some technical feedbacks which have been obtained as part of the process of fine-tuning the new technological systems that have been installed in the moot court. Interestingly, my students who were residing and studying online from overseas commented that they felt as if they were part of the moot and were sitting in the moot court in Australia. Several of my students also commented that they have found mooting to be fun and that the online mooting experience made learning more engaging and reduces the isolation that most external students feel.

The useful lesson that I had learnt in the project is that while the focus on technology is important, it is also important to ensure that the technology works for the students in a way which makes learning more effective. As such, the technological aspects of the project have been intertwined with the pedagogical aspects of the project, as well as the teaching space involved. 
What type(s) of learning and teaching are observed to take place?

It is interesting to note that my students have experienced a constructivist approach to learning as they come to discover and understand the gray areas in the law and moot points that they can argue. My students have learnt to analyse a legal problem, conduct research of the relevant law and present an oral argument. My students have learnt to engage with legal issues, and this has improved their skills of legal research, analysis and persuasive argument. Furthermore, as Lynch (1996) observes, the three characteristics of constructivism in Resnick's (1989) 'current cognitive theory' are present in moots. According to Resnick's 'current cognitive theory',

First, there is a process of knowledge construction, not of knowledge recording or absorption. Second, learning is knowledge-dependent; people use current knowledge to construct new knowledge. Third, learning is highly tuned to the situation in which it takes place.

Resnick's constructivist theory is present in moots as students learn the law and learn how to apply the law to the particular facts of the case that they are mooting.

It is also interesting that my students recognized the fact that this is how their future will be as lawyers, and welcome the new technology as something that they are very keen to learn so as to be better equipped as modern lawyers.

\section{Which aspects of the space design and equipment worked and which did not? Why?}

I have also sought for feedback from my students on whether they were satisfied with the space design and equipment. My students were very happy with the use of video in the mooting. Generally, feedback from the students was good. It is also noted that some of my students do not have a webcam for mooting purposes, and thus, there may be a need for these students to purchase new equipment to incorporate such mooting activities. Alternatively, CDU has an IT Kiosk, which loans such equipment to students.

Other best practices that are learnt in this project include ensuring that the microphone is turned off when not in use so as to reduce echoes in the audio. As for the moot court (and new teaching spaces), it would mean that the speakers should be situated far enough from the microphones.

Furthermore, the students need to learn to use the technology even as spectators as some of the students' feedbacks showed that some students were not able to use the full functionalities of Blackboard Collaborate ${ }^{\mathrm{TM}}$, such as enlarging the size of the video on their screens. These functions can only be done by the end users themselves, and as such, students need to improve their technical skills in using Blackboard Collaborate ${ }^{\mathrm{TM}}$ so as to have a good mooting experience, be it as online mooters or online spectators. Furthermore, some of my external students have suggested that they would prefer to be able to have a 360 degree view of the moot court. An internal student mooting in the moot court has suggested being given the option to use an ear piece which may make it easier to hear in the moot court as it would effectively eliminate any noise (if any). Of course, there is always room for more advanced technologies to be used if funding is available for it.

As the moot court in CDU Law School has been used as a teaching space as well as a moot court, many aspects of the CDU online moot court will continue to have features, which make it easy to convert the moot court to a teaching space. For example, the portable white board (with projector) is a useful feature as it allows for the teaching space to be converted into a 
moot court and vice versa easily by rolling it to different parts of the room - i.e., the white board is in front of the room when it is a teaching space, whilst it is situated at the back of the room when it is an online moot court. As an online moot court, the white board is useful for projecting large images of the external students who role play as lawyer, so that the moot court judge is able to see the external students as well as hear them when they are mooting.

Both the online moot court and the new teaching spaces (which are converted into make shift moot courts) are equipped with large screen TV screens which also assist in projecting images of external students role-playing as lawyers. Having mooting facilities in both the new teaching spaces as well as the online moot court at the law school itself is useful as it gives students more opportunity to moot online as there are more venues available for mooting. As Hernandez (1998) states, "we need more moot court not less".

\section{What technologies were most effective in enhancing learning and teaching? Why?}

The project has been able to ensure that the video and audio technology used in the moot court and the new teaching spaces can be used effectively for mooting. It was clear that the technology used had an impact on teaching and learning as without it, the external students simply would not be able to moot online. While there were initially problems for some students regarding lag in the audio (audio delays), which made following the moot sessions quite difficult, the students' feedback was helpful in solving these issues. This feedback revealed that students on $3 G$ wifi (slower internet connection) were generally able to hear clearly but students on faster internet connections had issues of lag. A second moot session was conducted but only after asking the students to slow down their internet connection settings within Blackboard Collaborate ${ }^{\mathrm{TM}}$ to the speed of $3 \mathrm{G}$ wifi if the students were using faster Internet connections such as the NBN Broadband. Thereafter, students have reported that the quality of the audio was good, with no lag at all. Those on NBN Broadband were able to hear better when they turned the speed down in Blackboard Collaborate ${ }^{\mathrm{TM}}$, although still with some minor (but tolerable) audio delays.

The omni-directional microphones were used in the moot court as the moot court is also a teaching space for lectures and tutorials. Thus, the omni-directional microphones would be useful when conducting tutorials where a few students in a small group are making discussions in class. It is also more economical (and fitted into the grant project's budget) as only 4 microphones are required in a tutorial class of 24 students. If a uni-directional microphone was used, more microphones would have to be purchased as it has a shorter capture range as compared to the omni-directional microphones.

\section{Online mooting helps online students form their own learning communities}

Mclnnerney and Roberts (2004) state that online students feel isolated when studying as they feel that they are studying alone, instead of engaging in group study. Therefore, they suggested that there should be social interaction to create a sense of community. This is akin to creating a learning community amongst the online students. The result of the Online Moot Project is encouraging as my online students seem to feel less isolated when they engage in online mooting. Indeed, mooting is a group activity, where the students will moot in a team. Hence, online mooting enabled the online students to interact with each other (as well as with internal students on campus) and form their own learning communities. 


\section{Conclusion}

One of the key advantages of the PST Framework is the fact that it takes three aspects into account: Pedagogy, Space and Technology. This is a more well balanced approach as otherwise, the practical scenario is one where the technical staff will be looking at the teaching spaces from a technological perspective, which then leaves less emphasis on other aspects, such as the pedagogical aspects. It also takes the students' (or end users') feedback into account. As technology is increasingly important in teaching and learning, the PST Framework has proven itself to be useful in the Online Moot Project. It would also be extremely useful in blended learning where the pedagogical, space and technological aspects of the PST Framework are all equally important.

The students in the Online Moot Project have worked in teams and this is valuable in online learning as most of the time, the online students study in isolation. This allows the students to form their own learning communities as they conduct research together, discuss the moot questions or plan their legal arguments with each other. Moot competitions are also very popular and allow for further engagement between the mooters at either domestic or international moot competitions, and this helps the students to grow their learning communities as they meet other mooters in these moot competitions.

\section{References}

Bransford, J.D., Brown, A.L., \& Cocking, R.R. (2000). How People Learn; Brain, Mind, Experience and School. Washington, DC: National Academies Press.

Brown, M.B. (2005). Learning Spaces. In D.G. Oblinger \& J.L. Oblinger (Eds.), Educating the Net Generation (pp. 12.1-12.22). EDUCAUSE. Available from http://www.educause.edu/ educatingthenetgen/.

Chickering, A.W., \& Gamson, Z.F. (1987). Seven Principles for Good Practice in Undergraduate Education. The American Association for Higher Education Bulletin.

Ehrmann, S. (1995). Asking the Right Questions: What does research tell us about technology and higher learning? Change, 27(2), 20-27.

Fraser, M., MacKenzie, J., Weisbrot, D., \& Tan, W. (2013). Transition from Legal Education to Practice: Extra-Curricular Competitions offer the Missing Link. Legal Education Review, 23(1), 131-152.

Gaubatz, J. (1981). Moot court in the modern law school. Journal of Legal Education, 31, 87-107.

Gerber, P., \& Castan, M. (2013). Practice meets theory: using moots as a tool to teach human rights law. Legal Education Digest, 21(1), 43.

Gygar, T., \& Cassimatis, A. (1997). Mooting Manual. Sydney, NSW: Butterworths.

Hernandez, M. (1998). In Defense of moot court: a response to 'In praise of moot court - not! Review of Litigation, 17, 69.

Jackson, S. (2008). Court-provided trial presentation technology- the Way of the Future? Proctor, 28(6), 58-60.

Jamieson P., Fisher, K., Gilding, T. \& Taylor, P. (2000). Place and Space in the Design of New Learning Environments. Higher Education Research and Development, 19(2), 221-237.

JISC. (2006). Designing Spaces for Effective Learning: A guide to 21st century learning space design. Retrieved from http://www.jisc.ac.uk/publications/publicatons/pub_spaces.aspx. 
Johnson, C., \& Lomas, C. (2005). Design of the Learning Space: Learning \& Design Principles. EDUCAUSE Review, 40(4), 16-28.

Koo, G. (2007). New Skills, New Learning: Legal Education and the Promise of Technology. Berkman Center for Internet \& Society, Harvard University. Retrieved from http://cyber.law.harvard.edu/ publications/2007/new_skills_new_learning.

Kozinski, A. (1997). In praise of moot court - not! Columbia Law Review, 97, 178-197.

Lebovits, G., Gewuerz, D. \& Hunker, C. (2013). Winning the Moot Court Oral Argument: A Guide for Intramural and Intermural Moot Court Competitors. Capital University Law Review, 41, 887.

Long, P.D., \& Ehrmann, S.C. (2005). Future of the Learning Space: Breaking Out of the Box. EDUCAUSE Review, 40(4), 43-58.

Lynch, A. (1996). Why do we Moot? Exploring the Role of Mooting in Legal Education. Legal Education Review, 7(1), 67.

Lynch, A. (1999). Packing them in the aisles: making use of moots as part of course delivery. 10 Legal Education Review, 83, 86-87.

Macrae, M. (2001). Academic Leader Calls for Action. eLaw Practice, 8, 21-24.

Mclnnerney, J.M., \& Roberts, T.S. (2004). Online learning: Social interaction and the creation of a sense of community. Educational Technology and Society, 7(3), 73-81.

Oblinger, D. (2005). Leading the Transition from Classrooms to Learning Spaces. EDUCAUSE Quarterly, $1,14-18$.

Pope, D. \& Hill, D. (2007). Mooting and Advocacy Skills. London: Sweet \& Maxwell.

Radcliffe, D., Wilson, H., Powell, D., \& Tibbetts, B. (Eds.) (2009). Learning Spaces in Higher Education: Positive Outcomes by Design. Proceedings of the Next Generation Learning Spaces 2008 Colloquium. Australia: The University of Queensland.

Resnick, L. (1989). Knowing, Learning and Instruction: Essays in Honour of Robert Glaser. Hillsdale, New Jersey: Lawrence Erlbaum Associates.

Richards, B. (2003). Alice comes to law school: The Internet as a teaching tool. Legal Education Review, 14(1), 115.

Siddall, S.E. (2006). The Denison Learning Space Project, Mission and Guiding Principles. Accessed 1 November 2015 from http://www.denison.edu/learningspaces/mission.html.

Snape, J., \& Watt, G. (2010). How To Moot: A Student Guide To Mooting (2nd edition). UK: Oxford University Press.

Thomas, M., \& Cradduck, L. (2013). The art of mooting: mooting and the cognitive domain. International Journal of the Legal Profession, 20(2), 223-237.

Tibbetts, B.W. (2008). Next Generation Learning Spaces Colloquium Report. Accessed 1 November 2015 from http://www.uq.edu.au/nextgenerationlearningspace/NGLSCollRep07.pdf.

Valiant, B. (1996). Turn on the Lights! Using What We Know about the Brain and Learning to Design Learning Environments. Issue Trak: A CEFPI Brief on Educational Facility Issues. Retrieved from http://www.cefpi.com/cefpi/issue/issue5.html.

Wilde, F. D. (2006). Courtroom Technology in Australian Courts: An Exploration into its Availability, Use and Acceptance. The Queensland Lawyer, 26, 303. 
Lord Woolf (July 1999). Access to Justice: Final Report to the Lord Chancellor on the Civil Justice System in England and Wales. Accessed 1 November 2015 from http://www.dca.gov.uk/civil/final/ index.htm.

Yule, J., McNamara, J., \& Thomas, M. (2012). Reality Bytes: Using Technology in Mooting. Queensland University of Technology Law and Justice Journal, 12(1), 89. 